\title{
DESKRIPSI KETERAMPILAN INTERPRETASI GRAFIK PESERTA DIDIK KELAS VIII \\ DI SMPN TERAKREDITASI A SE-KECAMATAN TAMALATE PADA MATERI GERAK LURUS
}

\section{Musdalifah *) \\ Universitas Negeri Makassar}

Sitti Rahma Yunus

Universitas Negeri Makassar

Muhammad Aqil Rusli Universitas Negeri Makassar
Abstrak: Penelitian ini bertujuan untuk mengetahui deskripsi keterampilan menginterpretasi grafik peserta didik kelas VIII di SMPN terakreditasi A seKecamatan Tamalate pada materi gerak lurus. Populasi penelitian ini adalah seluruh peserta didik SMPN terakreditasi A se-Kecamatan Tamalate sebanyak 1868 peserta didik. Sampel dipilih dengan teknik Random Sampling menggunakan Rumus Slovin sehingga sampel dalam penelitian ini adalah 329 peserta didik. Instrumen penelitian berupa soal pilihan ganda sebanyak 20 butir soal. Teknik pengumpulan data yaitu pemberian tes secara online melalui google form. Data dianalisis dengan analisis deskriptif kuantitatif. Nilai rata-rata keterampilan menginterpretasi grafik peserta didik pada materi gerak lurus yaitu 57,4 \% berada pada kategori kurang dengan persentase masing-masing aspek yaitu aspek memahami arti gradien pada grafik $64,3 \%$, aspek menentukan nilai data dari range variabel $66,4 \%$, aspek menentukan data variabel bebas dan terikat pada grafik $49,4 \%$, dan aspek menentukan hubungan antar variabel pada grafik $51,4 \%$.

Kata Kunci: Keterampilan interpretasi, Grafik, Gerak lurus.

Abstract: The purpose of this research is to describe students' graph interpretation skills in linear motion subject. The population of this research were 1868 students class VIII of SMPN accredited A in Tamalate District (SMPN 15 Makassar, SMPN 18 Makassar, SMPN 24 Makassar, SMPN 26 Makassar, and SMPN 27 Makassar). Sample was selected using the random sampling class technique and Slovin formula so the sample in this study was 329 students. The research instrument was multiple choice questions. The technique of collecting data is giving online tests via google form. Data were analyzed using quantitative descriptive analysis. The average skill of students in interpreting graphs on linear motion material is $57,4 \%$. The first indicator, understanding the meaning of the gradient at the graph, is $64.3 \%$, the second indicator, determining the value of the data from the variable range, is $66.4 \%$, the indicator determining the independent and dependent variable data on the chart, is $49.4 \%$, and the fourth indicator, determining the relationship between variables on the chart $51.4 \%$.

Keyword: Skill interpretation, graphics, linear motion.
*) Correspondence Author: Musdalifahh0105@gmail.com 


\section{PENDAHULUAN}

Kompetensi yang harus dicapai dalam pembelajaran IPA khususnya pada fisika berdasarkan Permendikbud No. 21 tahun 2016 tentang standar isi Pendidikan Dasar dan Menengah adalah merumuskan permasalahan yang berkaitan dengan fisika benda, merumuskan hipotesis, mendesain dan melaksanakan eksperimen, melakukan pengukuran secara teliti, mencatat dan menyajikan serta memahami arti tabel serta grafik, menyimpulkan dan melaporkan hasilnya secara lisan maupun tertulis (BNSP,2016). Dari beberapa kompetensi tersebut, keterampilan menginterpretasikan grafik merupakan salah satu keterampilan yang ditekankan kepada peserta didik Sekolah Menengah Pertama (SMP). Menginterpertasi grafik adalah pemahaman yang menghubungkan kemampuan verbal dan visual untuk meningkatkan pengetahuan konsep dan proses sains (Mustain, 2015). Dalam pembelajaran IPA, grafik dapat memuat berbagai informasi yang dapat ditemukan oleh pembacanya. Dengan membaca grafik diperoleh data-data. Keterampilan menggunakan grafik dalam IPA tidak sesederhana seperti menghubungkan atau menentukan titik- titik, tetapi lebih pada menterjemahkan grafik itu pada suatu kenyataan atau sebaliknya kenyataan diterjemahkan ke dalam sebuah grafik. Menggunakan grafik membutuhkan keterampilan khusus yaitu keterampilan menginterpretasi grafik.

Berbagai informasi yang berhubungan dengan pelajaran IPA khususnya fisika sering disajikan secara kuantitatif dalam bentuk grafik. Sehingga diperlukan keterampilan peserta didik dalam menginterpretasi grafik untuk menafsirkan informasi tersebut. Grafik juga digunakan untuk mempermudah dalam menafsirkan data-data angka hasil melakukan suatu eksperimen atau percobaan (Agustina, 2013). Salah satu materi IPA di SMP yang banyak membahas grafik adalah materi gerak lurus pada kompetensi dasar 3.2 yakni menganalisis gerak lurus, pengaruh gaya terhadap gerak berdasarkan Hukum Newton, dan penerapannya pada gerak benda dan gerak makhluk hidup. Pada materi gerak lurus, grafik memiliki peranan penting dalam menunjukkan, menggambarkan, dan menghitung variabel dari peristiwa gerak. Pada pokok bahasan gerak lurus, grafik dijadikan salah satu representasi untuk menjelaskan konsep gerak. Konsep-konsep gerak lurus meliputi jarak, kecepatan dan percepatan sering disajikan dalam bentuk grafik. Sehingga pentingnya peserta didik untuk mengetahuinya. Bentuk-bentuk gerakan partikel (benda) dapat diketahui dengan menelaah grafik gerak lurus (Subali, 2015).

Informasi yang disajikan dengan grafik tidaklah mudah dipahami oleh pembacanya. Khususnya bagi peserta didik SMP, penggunaan grafik dalam IPA masih banyak menimbulkan permasalahan. Hal ini sejalan dengan beberapa penelitian mengenai pemahaman menginterpretasi grafik dengan hasil penelitian yang menggambarkan kemampuan peserta didik yang masih kurang. Diantaranya penelitian yang dilakukan oleh Mustain (2015) yang meneliti tentang keterampilan membaca dan menginterpretasi grafik yang memperoleh data pencapaian rata-rata di bawah $50 \%$. Penelitian tersebut menunjukkan bahwa peserta didik pada kelas $D$ memperoleh Kriteria Ketuntasan Minimum (KKM) sebanyak 3,5\% tuntas dan 96,5\% remidial. Sedangkan pada kelas E Kriteria Ketuntasan Minimum (KKM) sebanyak 10\% tuntas dan 90\% remidial. Hasil penelitian tersebut menunjukkan bahwa peserta didik mengalami kesulitan dalam membaca dan menginterpretasi grafik. Selain itu berdasarkan studi yang dilakukan oleh Parmolo (2016) kemampuan menginterpretasi peserta didik SMP pada materi gerak lurus masih tergolong rendah dimana ada $60 \%$ peserta didik yang tidak dapat menentukan percepatan yang disajikan dalam bentuk grafik, dan ada 52,72\% peserta didik yang keliru dalam menyajikan grafik gerak lurus. Serta penelitian yang dilakukan oleh Ma'rifa (2016) yang menunjukkan bahwa pemahaman konsep gerak lurus peserta didik masih sangat rendah.

Berdasarkan hasil observasi kelima sekolah terakreditasi A di Kecamatan Tamalate yaitu SMPN 15 Makassar, SMPN 18 Makassar, SMPN 24 Makassar, SMPN 26 Makassar dan SMPN 27 Makassar ditemukan bahwa kegiatan pembelajaran yang dapat melatihkan keterampilan 
menginterpretasi grafik tidak terlaksana dengan maksimal. Di mana guru hanya menggunakan metode ceramah saat pembelajaran dan tidak menyajikan gambar atau grafik dalam pembelajaran materi gerak lurus. Berdasarkan hal tersebut maka peneliti melakukan penelitan dengan mengangkat judul "Deskripsi Keterampilan Interpretasi Grafik Peserta didik Kelas VIII di SMPN Terakreditasi A Se-Kecamatan Tamalate Pada Materi Gerak Lurus”.

\section{METODE}

Jenis penelitian yang digunakan adalah penelitian deskriptif kuantitatif. Penelitian deskriptif kuantitatif adalah penelitian yang menggunakan observasi, wawancara atau angket dengan hanya memberikan gambaran yang sebenarnya terkait fakta, keadaan dan peristiwa yang terjadi saat penelitian dilaksanakan dan menyajikan data hasil penelitian apa adanya. Dalam penelitian ini aspek yang teliti adalah keterampilan peserta didik dalam interpretasi grafik yang bertujuan untuk mengetahui deskripsi keterampilan menginterpretasi grafik peserta didik kelas VIII di SMPN terakreditasi A Se-Kecamatan Tamalate pada materi gerak lurus.

Populasi penelitian ini adalah seluruh peserta didik SMPN terakreditasi A Se-Kecamatan Tamalate sebanyak 1868 orang. Sampel dipilih dengan teknik Random Sampling menggunakan Rumus Slovin sehingga sampel dalam penelitian ini adalah 329 peserta didik. Instrumen penelitian berupa soal pilihan ganda sebanyak 20 butir soal pada materi gerak lurus dengan masing-masing pilihan jawaban setiap item soal adalah 4 opsi. Teknik pengumpulan data yaitu pemberian tes secara online melalui google form. Data dianalisis dengan analisis deskriptif kuantitatif. Metode yang digunakan adalah metode penskoran dari hasil tes siswa dan menghitung nilai persentase dari setiap kategori. Analisis stastistik deskriptif digunakan untuk menganalisis data dengan cara mendeskripsikan atau menggambarkan data yang telah terkumpul sebagaimana adanya tanpa bermaksud membuat kesimpulan yang berlaku untuk umum atau generalisasi.

\section{HASIL DAN PEMBAHASAN}

1. Hasil

a. Analisis Statistik Deskriptif Keterampilan Menginterpretasi Grafik Peserta Didik

Tabel 1. Hasil Analisis Statistik Deskriptif Keterampilan Menginterpretasi Grafik

\begin{tabular}{cc}
\hline Statistik Sampel & Keterangan \\
\hline Jumlah sampel & 329 \\
Nilai maksimum & 90 \\
Nilai minimum & 20 \\
Nilai rata-rata & 58,13 \\
Standar deviasi & 19,32 \\
Varians & 373,4 \\
\hline
\end{tabular}


Pada Tabel 1 menunjukkan nilai keterampilan interpretasi grafik peserta didik kelas VIII di SMPN Terakreditasi A Se-Kecamatan Tamalate. Nilai terendah peserta didik adalah 20 dan nilai tertinggi adalah 90. Dengan nilai rata-rata peserta didik yaitu 58,13.

\section{b. Persentase Keterampilan Menginterpretasi Grafik pada Materi Garis Lurus}

\section{Tabel 2. Persentase Keterampilan Menginterpretasi Grafik pada Materi Gerak Lurus}

\begin{tabular}{|c|c|c|c|}
\hline Interval Nilai (\%) & Menginterpretasi Grafik pada Materi Garis Lurus & Frekuensi & Persentase (\%) \\
\hline $86-100$ & Sangat Baik & 13 & 4.0 \\
\hline $76-85$ & Baik & 50 & 15.1 \\
\hline $60-75$ & Cukup & 96 & 29.2 \\
\hline $55-59$ & Kurang & 56 & 17.0 \\
\hline$\leq 54$ & Kurang Sekali & 114 & 34.7 \\
\hline \multicolumn{2}{|r|}{ Total } & 329 & 100 \\
\hline
\end{tabular}

Dari Tabel 2. persentase keterampilan menginterpretasi grafik dapat digambarkan sebagai berikut:

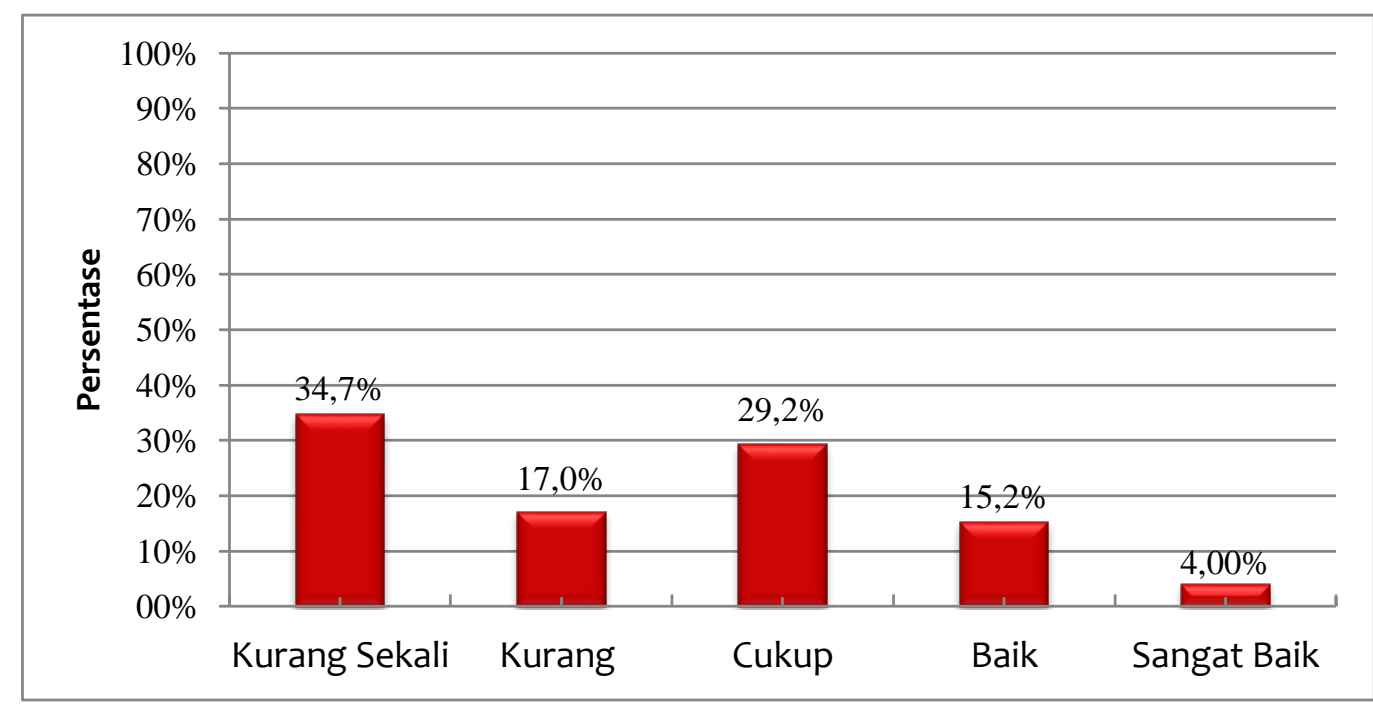

Gambar 1. Grafik Hasil Keterampilan Menginterpretasi Grafik pada Materi Garis Lurus

\section{c. Deskripsi Rata-Rata Masing- Masing Aspek}

Tabel 3 .Persentase Rata-Rata Aspek Keterampilan Menginterpretasi Grafik

\begin{tabular}{clcc}
\hline No. & \multicolumn{1}{c}{ Aspek } & Rata-Rata (\%) & Kategori \\
\hline 1. & Memahami arti gradien pada grafik & 64.3 & Cukup \\
2. & Menentukan nilai data dari range variabel & 66.4 & Cukup \\
3. & Menentukan data variabel bebas dan terikat pada grafik & 49.4 & Kurang sekali \\
4. & Menentukan hubungan antar variabel pada grafik & 51.4 & Kurang \\
& Rata-Rata & $57,4 \%$ & Kurang \\
\hline
\end{tabular}


Pada Tabel 3 menunjukkan bahwa aspek paling rendah yang dijawab benar oleh peserta didik adalah aspek menentukan variable bebas dan variable terikat. Aspek yang paling tinggi adalah aspek menentukan data dari range variable. Dari Tabel 3 persentase rata-rata masingmasing aspek keterampilan interpretasi grafik pada materi gerak lurus dapat digambarkan sebagai berikut:

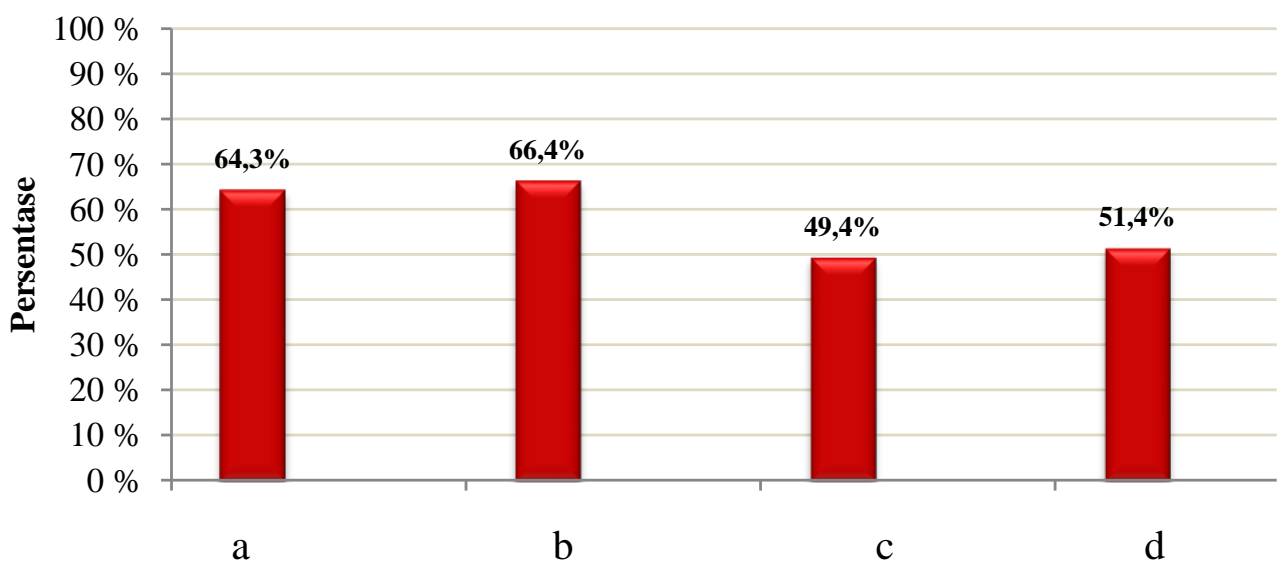

Gambar 2. Grafik Aspek Menginterpretasi Grafik

Keterangan : (a) Memahami arti gradien pada grafik (b) Menentukan nilai data dari range variabel (c) Menentukan data variabel bebas dan terikat (d) Menentukan hubungan antar variabel

\section{Pembahasan}

Berdasarkan dari penelitian yang dilakukan di SMPN terakreditasi A Se-Kecamatan Tamalate dengan jumlah peserta didik atau responden sebanyak 329 orang telah dilakukan analisis sesuai yang tercantum di atas dan dapat diketahui bahwa keterampilan peserta didik dalam menginterpretasi grafik berada dalam kategori kurang berdasarkan dari nilai yang diperoleh peserta didik dengan memiliki rata-rata yaitu $57,4 \%$. Hal ini sejalan dengan penelitian yang dilakukan oleh Setyono (2016) yang meneliti mengenai kemampuan peserta didik dalam memecahkan masalah fisika dalam bentuk grafik khususnya pada interpretasi grafik berada pada kategori kurang yaitu $48,30 \%$. Ada empat aspek yang dinilai dalam penelitian ini yaitu :

\section{Deskripsi Aspek Memahami Arti Gradien pada Grafik}

Keterampilan peserta didik kelas VIII di SMPN terakreditasi A Se-Kecamatan Tamalate terhadap pemahaman arti gradien pada grafik diperoleh rata-rata sebesar $64.3 \%$. Dengan demikian keterampilan peserta didik kelas VIII di SMPN terakreditasi A Se-Kecamatan Tamalate terhadap pemahaman arti gradien pada grafik termasuk dalam kategori cukup (Purwanto, 2013). Hal ini sejalan dengan penelitian yang dilakukan oleh Setyono (2016) mengenai kemampuan pemecahan masalah berbentuk grafik. Pada penelitian tersebut kesulitan peserta didik dalam menyelesaikan soal interpretasi grafik khususnya pada aspek memahami arti gradien pada grafik masih berada pada kategori kurang karena peserta didik dapat menghitung gradien pada grafik apabila dijelaskan terlebih dahulu mengenai arti dari grafik tersebut namun peserta didik kesulitan menyelesaikan soal pada aspek memahami arti gradien pada grafik apabila hanya disajikan gambar grafik. Selain itu menurut Setyono (2016) sebagian peserta didik mampu menghitung gradien pada grafik namun tidak mengetahui besaran apa yang dimaksud.

\section{Deskripsi Aspek Menentukan Nilai Data dari Range Variabel}


Keterampilan peserta didik kelas VIII di SMPN terakreditasi A Se-Kecamatan Tamalate terhadap penentuan nilai data dari range variabel diperoleh rata-rata sebesar $64.3 \%$. Dengan demikian kemampuan peserta didik kelas VIII di SMPN terakreditasi A Se-Kecamatan Tamalate terhadap penentuan nilai data dari range variabel termasuk dalam kategori cukup (Purwanto, 2013). Keterampilan menentukan nilai data dari range variable merupakan aspek paling tinggi yang dijawab benar oleh peserta didik diantara 4 aspek yang ada. Hal ini sejalan dengan penelitian yang dilakukan oleh Mukhtarin (2017) dimana aspek menentukan nilai data dari range variable berada pada kategori paling tinggi diantara empat aspek. Aspek menentukan nilai data dari range variabel berada pada kategori baik.

\section{Deskripsi Aspek Menentukan Data Variabel Bebas dan Terikat pada Grafik}

Keterampilan peserta didik kelas VIII di SMPN terakreditasi A Se-Kecamatan Tamalate terhadap penentuan data variabel bebas dan terikat pada grafik diperoleh rata-rata sebesar $49.4 \%$. Dengan demikian kemampuan peserta didik kelas VIII di SMPN terakreditasi A Se-Kecamatan Tamalate terhadap penentuan data variabel bebas dan terikat pada grafik termasuk dalam kategori kurang sekali (Purwanto, 2013). Hal ini sejalan dengan penelitian yang dilakukan oleh Mukhtarin (2017) dimana aspek menentukan data variable bebas dan variable terikat pada grafik berada pada kategori paling rendah diantara empat aspek. Aspek menentukan nilai data dari range variabel berada pada kategori kurang sekali. Menurut Hasbullah (2017) rendahnya keterampilan peserta didik dalam menyelesaikan soal grafik karena peserta didik belum memahami materi gerak lurus dengan baik. Pada saat diberikan soal tentang grafik gerak lurus peserta didik kesulitan dalam menyelesaikannya. Sebagaimana penelitian Pujianto (2013) ditemukan bahwa peserta didik yang memahami konsep gerak lurus hanya sebesar $21,7 \%$.

\section{Deskripsi Aspek Menentukan Hubungan antar Variabel pada Grafik}

Keterampilan peserta didik kelas VIII di SMPN terakreditasi A Se-Kecamatan Tamalate terhadap penentuan hubungan antar variabel pada grafik diperoleh rata-rata sebesar 51.4\%. Dengan demikian berdasarkan rata-rata kemampuan peserta didik kelas VIII di SMPN terakreditasi A SeKecamatan Tamalate terhadap penentuan hubungan antar variabel pada grafik termasuk dalam kategori kurang (Purwanto, 2013). Hal ini sejalan dengan penelitian yang dilakukan oleh Mukhtarin (2017) dimana aspek menentukan hubungan variable berada pada kategori kurang. Menurut Parmolo (2016) keterampilan interpretasi grafik khususnya pada aspek menghubungkan antar variabel berhubungan dengan kemampuan siswa dalam mengamati dan pemahaman konseptual. Kurangnya keterampilan peserta didik pada aspek ini dapat dipengaruhi oleh kemampuan pemahaman konsep gerak lurus dan juga pemahaman siswa dalam mengamati yang kurang.

\section{KESIMPULAN}

Berdasarkan hasil analisis data yang telah dilakukan diperoleh kesimpulan secara umum mengenai persentase keterampilan menginterpretasi grafik tentang gerak lurus peserta didik SMPN terakreditasi A Se-Kecamatan Tamalate memiliki rata-rata nilai yaitu 57,4\% yang berada pada kategori kurang. Secara khusus kesimpulan dalam penelitian ini adalah:

a. Aspek memahami arti gradien pada grafik yaitu $64,3 \%$ dalam kategori cukup

b. Aspek menentukan nilai data dari range variabel yaitu $66,4 \%$ dalam kategori cukup

c. Aspek menentukan data variabel bebas dan variabel terikat pada grafik yaitu $49,4 \%$ dalam kategori kurang sekali

d. Aspek menentukan hubungan antar variabel yaitu 51,4\% dalam kategori kurang 


\section{DAFTAR PUSTAKA}

Agustina, E. (2014). Penerapan Pembelajaran Model Kooperatif Tipe STAD Untuk Meningkatkan Hasil Belajar Aspek Kognitif dan Kemampuan Interpretasi Grafik Peserta didik SMP. (Skripsi). Fakultas Keguruan dan Ilmu Pendidikan Universitas Pendidikan Indonesia, Bandung.

BSNP. (2016). Standar Isi Pendidikan Dasar dan Menengah (online). (http://bsnpindonesia.org/standar-isi/, diakses 17 November 2020).

Hasbullah, dkk. (2017). Peningkatan Kemampuan Interpretasi Grafik Melalui Pendekatan MultiRepresentasi Pada Materi Gerak Lurus. Jurnal Universitas Serambi Mekah. Vol. 1.

Ma'rifa, dkk. (2016). Analisis Pemahaman Konsep Gerak Lurus pada Peserta didik SMA Negeri di Kota Palu. Jurnal Pendidikan Fisika Tadulako. Vol 4(3).

Mukhtarin,Wanti. (2017). Analisis Kemampuan Menginterpretasi Grafik Pada Materi KinematikaGerak Pada Peserta didik SMA di Kabupaten Jember. (Skripsi). Jember. Universitas Jember.

Mustain, I. (2015). Kemampuan Membaca dan Interpretasi Grafik dan Data: Studi Kasus pada Peserta didik Kelas 8 SMPN. Scientiae Educatia. Vol 5(2): 1-11.

Parmalo, Y.H. (2016). Deskripsi Kemampuan Menafsirkan Grafik Kinematika Peserta didik di Kelas $X$ SMA Negeri 3 Sungai Kakap. (Skripsi). Fakultas Keguruan dan Ilmu Pendidikan Universitas Tanjungpura, Pontianak.

Pujianto A., Nurjannah, \& Darmadi. (2013). Analisis Konsep Kinematika Gerak Lurus. Jurnal Pendidikan Fisika Tadulako. Vol 1(1).

Purwanto, M. N. 2013. Prinsip-prinsip dan Teknik EvaluasiPengajaran.Bandung: Remaja Rosdakarya.

Setyono, Anton.( 2016). Analisis Kesulitan Peserta didik Memecahkan Masalah Fisika Berbentuk Grafik dengan Tes Diagnostik. (Skripsi) Semarang : Universitas Negeri Semarang.

Subali, Bambang, dkk. (2015) .Analisis Kemampuan Interpretasi Grafik Kinematika pada Mahapeserta didik Calon Guru Fisika. http://portal.fi.itb.ac.id. Diakses 1 November 2015).

\section{Musdalifah}

Mahasiswa Program Studi Pendidikan IPA FMIPA UNM, dapat dihubungi melalui email: Musdalifahh0105@gmail.com

\section{Sitti Rahma Yunus}

Dosen Program Studi Pendidikan IPA FMIPA UNM, aktif melakukan penelitian pada bidang Pendidikan IPA, dapat dihubungi melalui email: sitti.rahma.yunus@unm.ac.id

\section{Muhammad Aqil Rusli}

Dosen Program Studi Pendidikan IPA FMIPA UNM, aktif melakukan penelitian pada bidang Pendidikan IPA, dapat dihubungi melalui email: m.aqilrusli@gmail.com 